\title{
Organic substrates and slow-realease fertilizing on nutrient accumulation and absorption efficiency of custard apple seedlings
}

\author{
Scheila Antunes Amorim ${ }^{1} \oplus$, Augusto Miguel Nascimento Lima ${ }^{1 *} \mathbb{0}$, Ítalo Herbert Lucena Cavalcante ${ }^{1}$, \\ Jailson Cavalcante Cunha' ${ }^{1}$, Júlio César Ferreira de Melo Júnior ${ }^{1} \oplus$, Kátia Araújo da Silva ${ }^{1} \oplus$, \\ Marcos Sales Rodrigues ${ }^{1}\left[\right.$, Dayanne do Nascimento Dias $^{1}{ }^{10}$

\footnotetext{
1 Universidade Federal do Vale do São Francisco, Petrolina, PE, Brasil. E-mail: augusto.lima@univasf.edu.br; scheila.antunes@univasf.edu.br; italo.cavalcante@univasf.edu.br; jailson.c.c@gmail.com; julio.melo@univasf.edu.br; katia_a.s@outlook.com; marcos.rodrigues@univasf.edu.br; dayanne-dias@outlook.com
}

ABSTRACT: There is a lack of agronomic research on the production of custard apple seedlings, especially regarding the ideal substrate and nutritional requirement of the plants. In order to evaluate the accumulation of nutrients in shoots and roots, leaf chlorophyll index and absorption efficiency index (AEI) in custard apple seedlings grown in different substrates and under doses of slow-release fertilizer, an experiment was set in randomized blocks in split-plot scheme with four replicates and eleven plants per plot. The custard apple seedling production method was by sowing. Plots were represented by substrates (fresh sugarcane bagasse; enriched sugarcane bagasse; coconut powder, and commercial organic substrate), whereas subplots were represented by Osmocote Plus ${ }^{\circledR}$ fertilizer doses $\left(0 ; 3 ; 6 ; 9 ; 12\right.$ and $\left.15 \mathrm{~kg} \mathrm{~m}^{-3}\right)$. The final evaluation was performed at 105 days after sowing. The effect of the slow-release fertilizer on the formation of custard apple seedlings was influenced by the substrate. There was greater accumulation of nutrients as the availability of nutrients increases, as well as increase in nutrient AEI. Custard apple seedlings were found to be more efficient to absorb $\mathrm{N}>\mathrm{Mg}>\mathrm{K}>\mathrm{Ca}>\mathrm{P}>\mathrm{Fe}>\mathrm{Mn}>\mathrm{Zn}$. As substrate, coconut powder associated with the $9 \mathrm{~kg} \mathrm{~m}^{-3}$ slow-release fertilizer dose is recommended to produce custard apple seedlings.

Key words: Annona squamosa L.; organic residues; plant nutrition; seedling quality

\section{Substratos orgânicos e fertilizante de liberação lenta na acumulação de nutrientes e na eficiência de absorção de nutrientes de mudas de pinheira}

RESUMO: Há carência de estudos agronômicos sobre a produção de mudas de pinheira ou fruta do conde, sobretudo quanto ao substrato ideal e à necessidade nutricional das plantas. Com o objetivo de avaliar o acúmulo de nutrientes na parte aérea e sistema radicular, os índices de clorofila foliar e de eficiência de absorção (IEA) em mudas de pinheira cultivadas em diferentes tipos de substratos e doses de fertilizante de liberação lenta, foi realizado um experimento em blocos casualizados em esquema de parcelas subdivididas com quatro repetições e onze plantas por parcela, sendo definido como parcela o fator substrato (bagaço de cana-de-açúcar in natura; bagaço de cana-de-açúcar enriquecido; pó de coco; e substrato orgânico comercial Tropstrato ${ }^{\circledR}$ ), e como subparcela as doses do fertilizante Osmocote Plus ${ }^{\circledR}\left(0 ; 3 ; 6 ; 9 ; 12\right.$ e $\left.15 \mathrm{~kg} \mathrm{~m}^{-3}\right)$. 0 método de produção de mudas de pinheira foi por semeadura. A avaliação final do experimento foi realizada aos 105 dias após a semeadura. $O$ efeito do fertilizante de liberação lenta foi influenciado pelo substrato na formação de mudas de pinheira. Houve maiores acúmulos de nutrientes com o aumento da disponibilidade de nutrientes, assim como aumento do IEA de nutrientes. As mudas de pinheira mostraram-se mais eficientes em absorver $\mathrm{N}>\mathrm{Mg}>\mathrm{K}>\mathrm{Ca}>\mathrm{P}>\mathrm{Fe}>\mathrm{Mn}>\mathrm{Zn}$. Recomenda-se como substrato o pó de coco associado ao fertilizante de liberação lenta na dose de $9 \mathrm{~kg} \mathrm{~m}^{-3}$ para a produção de mudas de pinheira.

Palavras-chave: Annona squamosa L.; resíduos orgânicos; nutrição de plantas; qualidade de mudas

\footnotetext{
*Augusto Miguel Nascimento Lima - E-mail: augusto.lima@univasf.edu.br (Corresponding author)

Associate Editor: Sérgio Ruffo Roberto
} 


\section{Introduction}

In Northeast Brazil, the cultivation of custard apple is in full expansion, and irrigated fruit production stands out as the main agribusiness activity in the São Francisco Valley, nevertheless, despite the great agro-industrial potential, this region faces problems with the scarcity of good-quality seedlings for the planting of new orchards (Melo Júnior et al., 2015), including of custard apple.

Using regional materials from the local agro-industry as potential substrates for seedling production may lead to reduction in the environmental impact, minimizing production costs and presenting itself as a feasible alternative for farmers. Nonetheless, it is important to remember that the substrate must have good cation exchange capacity, physical stability and biological sterility, besides adequate $\mathrm{pH}$, electrical conductivity, nutrient contents, $\mathrm{C} / \mathrm{N}$ ratio, water/air ratio, total porosity, water retention capacity and drainage (Barreto et al., 2018).

Among agroindustry wastes, those from sugarcane industry stand out, such as fresh sugarcane bagasse, used by local farmers of mango and grape for soil mulching, and enriched sugarcane bagasse, which is an organic compound formed by mixing sugarcane bagasse, filter cake, sugarcane washing sludge and vinasse, and used as organic fertilizer by local farmers. In addition, there are wastes from other industries such as the coconut one and, according to Sá et al. (2015), for every $250 \mathrm{~cm}^{3}$ of coconut water bottled in Brazilian semi-arid, $1 \mathrm{~kg}$ of residue (shell) is generated and a fair portion of these shells is discarded, constituting a major environmental problem.

Fertilization of fruit crops using fertilizer sources with slow or controlled nutrient release is efficient and enables continuous nutrient availability, therefore, lower occurrence of deficiency and lower nutrient losses through leaching, making split applications of other sources unnecessary and reducing costs (Almeida et al., 2019).

Custard apple is a high nutrient demand plant if compared with other commercial fruit crops, such as pineapple, avocado, orange, banana and soursop (Cavalcante et al., 2012), but there are almost no reports in the scientific literature on its nutrient accumulation, especially during seedling production stage.

Hence, the present study aimed to evaluate the nutrient accumulation, leaf chlorophyll index and nutrient absorption efficiency in custard apple seedlings produced in different organic substrates under six slow-release fertilizer doses.

\section{Materials and Methods}

\section{Plant materials and growth conditions}

Custard apple (Annona squamosa L.) seeds were obtained from fruits commercialized in the commercial market. Ripe custard apples were manually pulped to remove the seeds, which were then soaked in water for $24 \mathrm{~h}$.

The study was conducted in two cycles of production of custard apple seedlings, the first one from May 29 to September 15,2015 , and the second one from March 18 to July 4, 2016, in screened nursery (50\% shade) at Universidade Federal do Vale do São Francisco, Petrolina county, Pernambuco state, Brazil. According to Köppen's classification, the climate of the region is BSwh, very hot and dry steppe climate. Monthly means of climatic variables for temperature, relative air humidity and rainfall recorded along the experiment were 26.32 으, $56.38 \%$ and $8 \mathrm{~mm}$, respectively.

\section{Treatments and experimental design}

The experimental design was randomized blocks in splitplot scheme, with four replicates and eleven plants per plot. Plots were represented by four organic substrates: fresh sugarcane bagasse; enriched sugarcane bagasse (obtained by composting fresh sugarcane bagasse, cake filter, sugarcane washing sludge and vinasse); coconut powder; and commercial substrate Tropstrato ${ }^{\circ}$. Each plot was subdivided into six subplots, represented by the doses of the slow-release fertilizer Osmocote Plus (NPK 15-9-12): 0, 3, 6, 9, 12 and 15 $\mathrm{kg} \mathrm{m} \mathrm{m}^{-3}$.

The fertilizer Osmocote Plus ${ }^{\bullet} 15-9-12$ has minerals coated by a membrane that allows slow supply, along three to four months, and composition of $15 \%$ nitrogen (N), $9 \%$ phosphorus $\left(\mathrm{P}_{2} \mathrm{O}_{5}\right), 12 \%$ potassium $\left(\mathrm{K}_{2} \mathrm{O}\right), 1.3 \%$ magnesium $(\mathrm{Mg}), 5.9 \%$ sulfur (S), 0.02\% boron (B), 0.05\% copper (Cu), 0.46\% iron (Fe), $0.02 \%$ manganese $(\mathrm{Mn}), 0.02 \%$ molybdenum (Mo) and $0.05 \%$ zinc (Zn). The commercial substrate Tropstrato ${ }^{\circ}$ is composed of pine bark, peat and expanded vermiculite.

The substrates were characterized physically and chemically (Table 1). Physical characteristics were determined using the method described in the Normative Instruction of $\mathrm{n}$ 17, of May 21, 2007, from the Ministry of Agriculture, Livestock

Table 1. Chemical and physical attributes of the substrates fresh sugarcane bagasse (S1), enriched sugarcane bagasse (S2), coconut powder (S3) and commercial substrate (S4) used in the experiment.

\begin{tabular}{|c|c|c|c|c|}
\hline Characteristics & S1 & S2 & S3 & S4 \\
\hline $\mathrm{pH}$ & 7.1 & 7.9 & 5.8 & 6.0 \\
\hline $\mathrm{EC}^{1 /}\left(\mathrm{dS} \mathrm{m}^{-1}\right)$ & 0.9 & 1.1 & 0.4 & 0.5 \\
\hline $\mathrm{C}\left(\mathrm{g} \mathrm{kg}^{-1}\right)$ & 522 & 146 & 350 & 18 \\
\hline $\mathrm{N}\left(\mathrm{g} \mathrm{kg}^{-1}\right)$ & 3.8 & 8.4 & 5.8 & 3.8 \\
\hline$P\left(g_{k g}{ }^{-1}\right)$ & 2.0 & 6.6 & 2.4 & 3.1 \\
\hline $\mathrm{K}\left(\mathrm{g} \mathrm{kg}^{1}\right)$ & 6.5 & 9.0 & 10.5 & 6.5 \\
\hline $\mathrm{Ca}\left(\mathrm{g} \mathrm{kg}^{-1}\right)$ & 3.2 & 22.8 & 5.7 & 9.2 \\
\hline $\mathrm{Mg}\left(\mathrm{g} \mathrm{kg}^{-1}\right)$ & 0.6 & 3.9 & 1.4 & 14.0 \\
\hline $\mathrm{Na}\left(\mathrm{g} \mathrm{kg}^{-1}\right)$ & 0.2 & 0.5 & 0.7 & 0.4 \\
\hline $\mathrm{Fe}\left(\mathrm{mg} \mathrm{kg}^{-1}\right)$ & 841 & 17.620 & 780 & 7.180 \\
\hline $\mathrm{Mn}\left(\mathrm{mg} \mathrm{kg}^{-1}\right)$ & 36 & 592 & 27 & 164 \\
\hline $\mathrm{Zn}\left(\mathrm{mg} \mathrm{kg}^{-1}\right)$ & 14 & 110 & 25 & 32 \\
\hline$B\left(\mathrm{mg} \mathrm{kg}^{-1}\right)$ & 5 & 14 & 24 & 13 \\
\hline$C / N$ & $137 / 1$ & $17 / 1$ & $60 / 1$ & $5 / 1$ \\
\hline $\mathrm{OM}^{2 /}\left(\mathrm{g} \mathrm{kg}^{-1}\right)$ & 900 & 252 & 604 & 30.4 \\
\hline $\mathrm{CEC}^{3 /}\left(\mathrm{mmol}_{\mathrm{c}} \mathrm{dm}^{-3}\right)$ & 144.1 & 161.1 & 383.5 & 292.6 \\
\hline $\operatorname{Dsub}^{4 /}\left(\mathrm{kg} \mathrm{m}^{-3}\right)$ & 518.6 & 644.5 & 504.6 & 538.1 \\
\hline $\mathrm{TP}^{5 /}(\%)$ & 26 & 32 & 73 & 43 \\
\hline Moisture (\%) & 12 & 15 & 83 & 40 \\
\hline
\end{tabular}

1/Electrical Conductivity (EC); ${ }^{2 /}$ Organic Matter (OM); ${ }^{3 / C a t i o n ~ E x c h a n g e ~ C a p a c i t y ~(C E C) ; ~}{ }^{4 /}$ Density (Dsub); ${ }^{5 /}$ Total Porosity. 
and Food Supply (MAPA, 2007). Chemical characteristics (macro- and micronutrients) were determined according to the methodology described by Malavolta et al. (1997).

Substrates were arranged on 16 benches (tanks) $(1.2$ $\mathrm{m}$ long $\times 0.6 \mathrm{~m}$ wide $\times 0.8 \mathrm{~m}$ high). Each fertilizer dose was applied in three rows with eleven plants arranged alternately, guaranteeing minimum spacing of $10 \mathrm{~cm}$ between plants, which were representative of the subplots.

To plant the seeds, each substrate and the slow-release fertilizer were manually mixed, with the aid of shovel and hoe. Tubes ( $0.131 \mathrm{~m}$ high and $180 \mathrm{~cm}^{3}$ volume) were manually filled with the mixture (substrate + Osmocote $^{\circ}$ ) and arranged side by side on trays. The substrate coconut powder was subjected to washing prior to sowing to eliminate the excess of $\mathrm{Na}^{+}$ions.

Seeds were planted at approximately $1.0 \mathrm{~cm}$ depth. Then, vermiculite was added on the substrate and the first irrigation was applied using a watering can.

A sub-irrigation system, in which tubes were partially immersed in water for five minutes, was used to irrigate the substrate, twice a day, at $9 \mathrm{~h}$ and $15 \mathrm{~h}$, to ensure full moistening. The experiment was monitored and there were no phytosanitary problems. Plants were thinned at 45 days after sowing (DAS), when seedlings showed two vigorous true leaves, leaving only the most developed seedling.

\section{Variables recorded and statistical analyses}

The final evaluation of the experiment was carried out at 105 DAS. Relative indexes of chlorophyll $a, b$ and total were determined in the second pair of leaves, in two leaves per plant. Readings were taken on the leaf blade in such a way that the instrument did not come into contact with the midrib, using a portable chlorophyll meter (ClorofiLog Falker', Brazil). Shoots and root systems of custard apple seedlings were separated in the nursery and taken to the laboratory, where they were washed with distilled water and dried in forced air circulation oven at $65-70{ }^{\circ} \mathrm{C}$ until constant weight. Then, the material was weighed to determine shoot and root dry matter.

After the plant material was dried and ground in a Wileytype mill, 0.5 -g portions of these samples were mineralized by dry digestion to determine the contents of macro- and micronutrients, according to methodologies described by
Teixeira et al. (2017): I) Phosphorus (P): determined by UV visible spectrophotometry; II) Potassium (K) and Sodium (Na): determined by flame emission photometry; III) Calcium (Ca) and Magnesium (Mg): determined by atomic absorption spectrophotometry; IV) Iron (Fe), Manganese (Mn) and Zinc $(\mathrm{Zn})$ : determined by atomic absorption spectrophotometry. Nitrogen was determined in solutions obtained from extracts prepared by sulfuric acid digestion, using the Kjeldahl method, according to Teixeira et al. (2017). The chemical analyses provided the contents of $\mathrm{P}, \mathrm{K}, \mathrm{Na}, \mathrm{Fe}, \mathrm{Mn}, \mathrm{Zn}$ and $\mathrm{N}$ in the shoots and roots of custard apple seedlings.

Contents of nutrients and dry matter of the plants were used to calculate the total contents of nutrients in the shoots and roots of custard apple seedlings. In addition, nutrient absorption efficiency indexes (AEI) were calculated using the equation described by Swiader et al. (1994): AEI = total nutrient content in the plant/root system dry matter.

The data were subjected to analysis of variance by $F$ test at 0.05 probability level. When significant, means of characteristics relative to the evaluated types of substrates were compared by Scott-Knott test. Interactions between factors considered as significant, by $F$ test at 0.01 and 0.05 probability levels, were subjected to regression analysis.

\section{Results}

There was significant interaction between substrates and doses of the slow-release fertilizer for the nutrient contents in shoots and roots of custard apple seedlings, as well as for the indexes of leaf chlorophyll $a, b$ and total (Tables 2 and 3 ).

The substrates containing enriched sugarcane bagasse and coconut powder promoted linear increase of $\mathrm{N}$ shoot content of custard apple seedlings as a function of the increment in slow-release fertilizer doses (Figure 1a). From the nonfertilized treatment to the highest slow-release fertilizer dose, relative $\mathrm{N}$ shoot accumulation, was substantially higher for substrate coconut powder $(542.6 \%)$, while $101.6 \%$ was recorded for substrate enriched sugarcane bagasse. In the substrates fresh sugarcane bagasse and commercial substrate, maximum $\mathrm{N}$ accumulation corresponded to 20.65 and 20.54 $\mathrm{mg}$ plant $^{-1}$, respectively.

Table 2. Contents of nitrogen, phosphorus, calcium, magnesium, potassium, sodium, iron, manganese and zinc in the shoots and indexes of chlorophyll $\mathrm{a}, \mathrm{b}$ and total in custard apple seedlings as a function of different substrates and doses of slowrelease fertilizer.

\begin{tabular}{|c|c|c|c|c|c|c|c|c|c|c|c|c|}
\hline \multirow{2}{*}{ Substrate $^{1 /}$} & $\mathbf{N}$ & $\mathbf{P}$ & $\mathrm{Ca}$ & $\mathrm{Mg}$ & K & $\mathrm{Na}$ & $\mathrm{Fe}$ & $\mathrm{Mn}$ & $\mathrm{Zn}$ & \multirow{2}{*}{ Cha } & \multirow{2}{*}{$C h b$} & \multirow{2}{*}{ Total ch } \\
\hline & \multicolumn{9}{|c|}{ (mg plant $\left.{ }^{1}\right)$} & & & \\
\hline$\overline{\text { S1 }}$ & $14.19 c^{2 /}$ & $3.35 \mathrm{c}$ & $5.52 c$ & $1.81 \mathrm{~d}$ & $6.92 \mathrm{~d}$ & $0.00015 b$ & $0.029 d$ & $0.060 \mathrm{a}$ & $0.011 \mathrm{~b}$ & $30.40 \mathrm{~b}$ & $8.71 \mathrm{a}$ & $39.12 \mathrm{~b}$ \\
\hline 52 & $16.68 \mathrm{~b}$ & $3.79 \mathrm{~b}$ & $16.11 \mathrm{a}$ & $3.11 \mathrm{c}$ & $15.38 \mathrm{~b}$ & $0.00034 \mathrm{a}$ & $0.032 c$ & $0.026 c$ & $0.013 b$ & $32.25 \mathrm{a}$ & $8.31 \mathrm{a}$ & $40.56 \mathrm{a}$ \\
\hline 33 & $20.26 \mathrm{a}$ & $5.44 \mathrm{a}$ & $16.81 \mathrm{a}$ & $5.90 \mathrm{~b}$ & $18.66 \mathrm{a}$ & $0.00031 \mathrm{a}$ & $0.051 \mathrm{~b}$ & 0.062 a & 0.022 a & $9 \mathrm{~b}$ & $8.72 \mathrm{a}$ & $51 \mathrm{~b}$ \\
\hline S4 & $14.95 c$ & $3.55 c$ & $12.23 \mathrm{~b}$ & $8.01 \mathrm{a}$ & $10.77 \mathrm{c}$ & $0.00031 \mathrm{a}$ & $0.058 \mathrm{a}$ & $0.053 \mathrm{~b}$ & $0.012 \mathrm{~b}$ & $31.76 \mathrm{a}$ & $9.15 \mathrm{a}$ & 40.91 a \\
\hline CV (\%) & .97 & 10.69 & 27.84 & 28.86 & 21.72 & 28.79 & 12.39 & 24.38 & 31.61 & 3.65 & 9.74 & 4.59 \\
\hline SV & \multicolumn{12}{|c|}{ F-value ${ }^{3 /}$} \\
\hline Substrate (S & $64.53^{* *}$ & $117.54 * *$ & $51.64^{* *}$ & $100.81 * *$ & $80.75 * *$ & $27.67^{* *}$ & $169.04^{* *}$ & $42.88 * *$ & $25.53^{* *}$ & $13.26^{*}$ & $3.90^{\text {ns }}$ & $5.11^{*}$ \\
\hline Dose $(D)^{4 /}$ & $271.88^{* *}$ & $206.36^{* *}$ & $81.44^{* *}$ & $40.93 * *$ & $84.25^{* *}$ & $52.77^{* *}$ & $60.84^{* *}$ & $89.34^{* *}$ & $38.91^{* *}$ & $741.74^{* *}$ & $547.79 * *$ & $794.90 * *$ \\
\hline$S \times D$ & $13.70 * *$ & $12.43^{* *}$ & $8.53^{* *}$ & $11.78^{* *}$ & $8.75^{* *}$ & $3.60 * *$ & $7.29 * *$ & $8.2 * *$ & $7.90^{* *}$ & $33.66 * *$ & $15.67 * *$ & $30.55^{* *}$ \\
\hline
\end{tabular}

${ }^{1 / S 1}$, fresh sugarcane bagasse; S2, enriched sugarcane bagasse; S3, coconut powder; S4, commercial substrate. ${ }^{2 / M e a n s}$ followed by the same letter in the column do not differ statistically by Scott-Knott test. ${ }^{3 / n s},{ }^{*}$ and ${ }^{* *}$ indicate not significant, significant at 0.05 and 0.01 probability levels, respectively. ${ }^{4 / O s m o c o t e}{ }^{\circ}$ dose. 
Table 3. Contents of nitrogen, phosphorus, calcium, magnesium, potassium, sodium, iron, manganese and zinc in the root system of custard apple seedlings as a function of different substrates and doses of slow-release fertilizer.

\begin{tabular}{|c|c|c|c|c|c|c|c|c|c|}
\hline \multirow{2}{*}{ Substrate $^{1 /}$} & $\mathbf{N}$ & $\mathbf{P}$ & $\mathrm{Ca}$ & $\mathrm{Mg}$ & $\bar{K}$ & $\mathrm{Na}$ & $\mathrm{Fe}$ & $\mathrm{Mn}$ & $\mathrm{Zn}$ \\
\hline & \multicolumn{9}{|c|}{ (mg plant $^{-1}$ ) } \\
\hline S1 & $11.33 c^{2 /}$ & $3.47 \mathrm{~b}$ & $9.19 \mathrm{c}$ & $17.78 \mathrm{c}$ & $18.34 \mathrm{c}$ & $0.31 \mathrm{c}$ & $0.11 \mathrm{c}$ & $0.014 \mathrm{~b}$ & $0.013 \mathrm{~b}$ \\
\hline S2 & $15.82 b$ & $3.68 \mathrm{~b}$ & $18.73 b$ & $27.33 b$ & $26.13 b$ & $0.42 b$ & $0.27 a$ & $0.019 b$ & $0.015 b$ \\
\hline S3 & $20.71 \mathrm{a}$ & $6.03 \mathrm{a}$ & $25.19 \mathrm{a}$ & 39.67 a & $37.72 \mathrm{a}$ & $0.75 \mathrm{a}$ & $0.13 c$ & $0.038 \mathrm{a}$ & $0.036 \mathrm{a}$ \\
\hline \$4 & $16.98 b$ & $3.51 b$ & $18.18 \mathrm{~b}$ & 37.82 a & $29.09 b$ & $0.43 b$ & $0.19 b$ & 0.038 a & $0.014 \mathrm{~b}$ \\
\hline CV (\%) & 19.25 & 16.81 & 17.14 & 25.56 & 23.28 & 28.99 & 32.10 & 29.34 & 33.99 \\
\hline Source of variation & \multicolumn{9}{|c|}{ F-value ${ }^{3 /}$} \\
\hline Substrate (S) & $36.78^{* *}$ & $75.04^{* *}$ & $111.24^{* *}$ & $40.33^{* *}$ & $36.65^{* *}$ & $43.89 * *$ & $38.86^{* *}$ & $57.16^{* *}$ & $61.06 * *$ \\
\hline Dose $(D)^{4 /}$ & $192.33^{* *}$ & $196.63 * *$ & $76.03 * *$ & $46.81 * *$ & $43.43^{* *}$ & $34.61^{* *}$ & $44.33^{* *}$ & $48.83^{* *}$ & $15.70 * *$ \\
\hline$S \times D$ & $16.70 * *$ & $20.16^{* *}$ & $13.26 * *$ & $6.22 * *$ & $6.01 * *$ & $11.57^{* *}$ & $5.43^{* *}$ & $7.64 * *$ & $4.26 * *$ \\
\hline
\end{tabular}

${ }^{1 / S 1}$, fresh sugarcane bagasse; S2, enriched sugarcane bagasse; S3, coconut powder; S4, commercial substrate. ${ }^{2 /}$ Means followed by the same letter in the column do not differ statistically by Scott-Knott test. ${ }^{3 / n s}$, * and ${ }^{* *}$ indicate not significant, significant at 0.05 and 0.01 probability levels, respectively. ${ }^{4 / O}$ smocote ${ }^{\circ}$ dose.
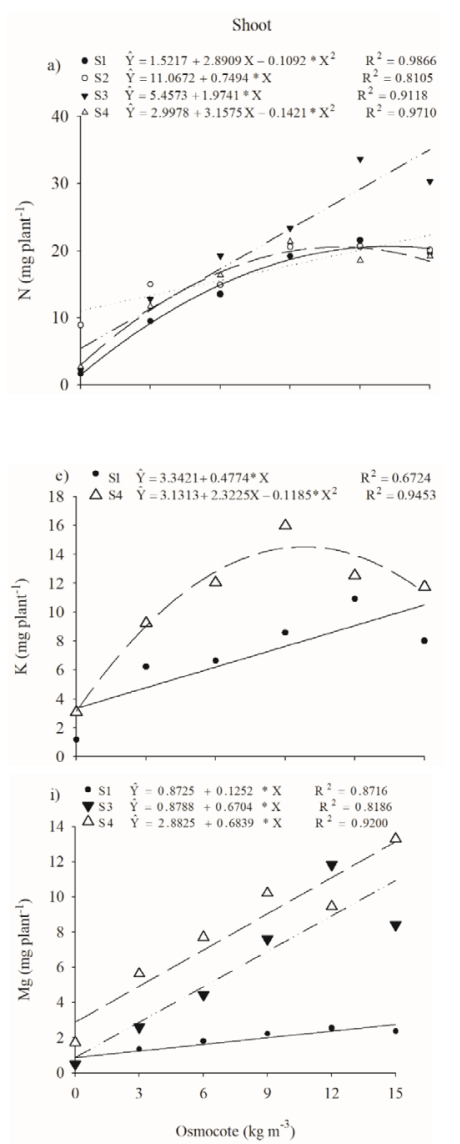
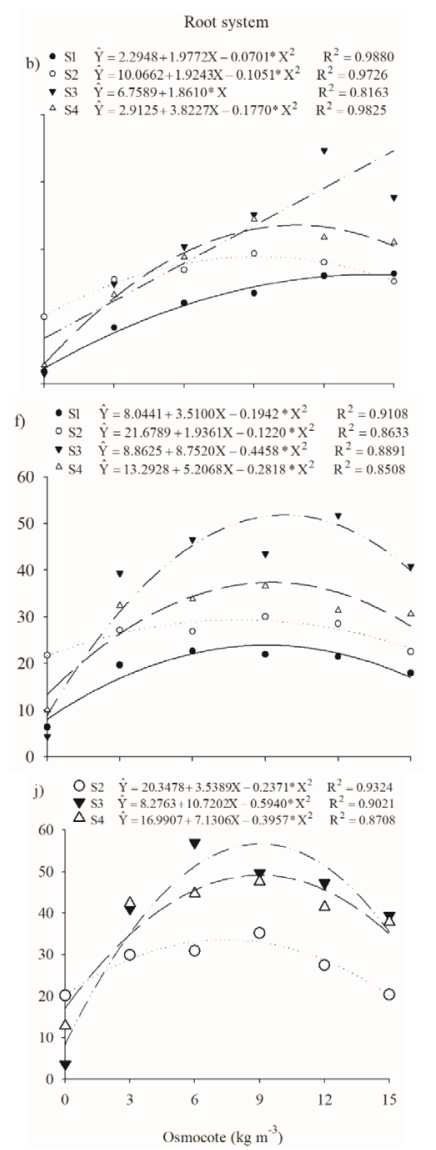
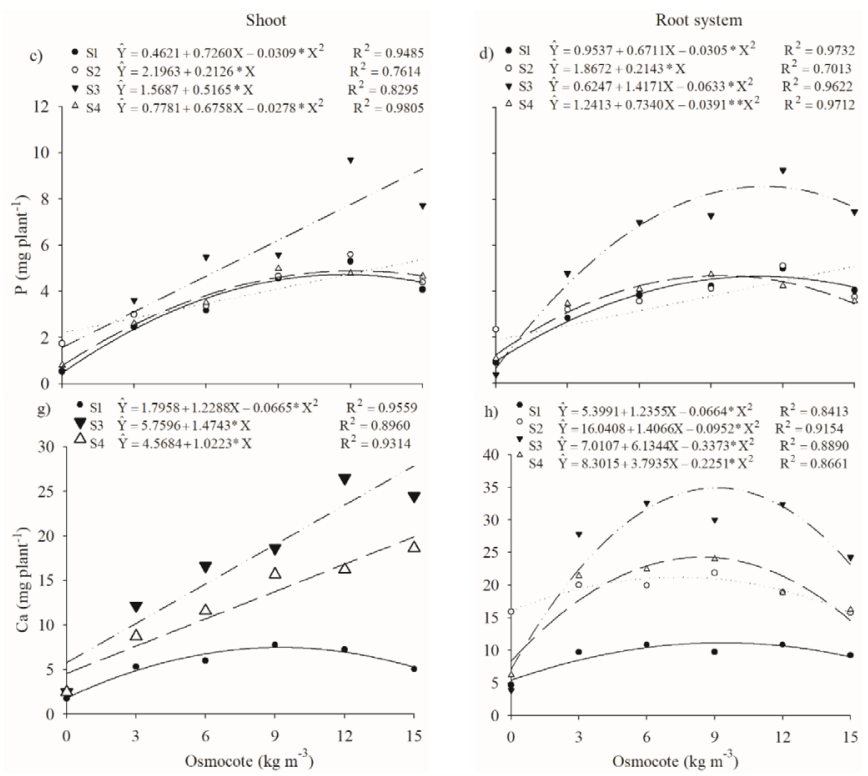

Figure 1. Contents of nitrogen $(a, b)$, phosphorus $(c, d)$ and potassium $(e, f)$, calcium $(g, h)$ and magnesium $(i, j)$ in shoots and roots of custard apple seedlings as a function of different substrates and doses of slow-release fertilizer. **, *significant at 0.01 and 0.05 probability levels by t-test, respectively. S1, fresh sugarcane bagasse; S2, Enriched sugarcane bagasse; S3, Coconut powder; $\$ 4$, commercial substrate.

$\mathrm{N}$ root accumulation showed a similar tendency to that recorded for shoots, except for substrate enriched sugarcane bagasse, in which maximum accumulation occurred at the estimated slow-release fertilizer dose of $9.15 \mathrm{~kg} \mathrm{~m}^{-3}$ (Figure 1b).

The substrate coconut powder led to higher $P$ accumulation in the shoots and roots of custard apple seedlings (9.32 and $8.55 \mathrm{mg} \mathrm{plant}^{-1}$, at slow-release fertilizer doses of 15 and $11.19 \mathrm{~kg} \mathrm{~m}^{-3}$, respectively) (Figure $1 \mathrm{c}$ and $1 \mathrm{~d}$ ). No significant regression models were found for $\mathrm{K}$ accumulation in the shoots of custard apple seedlings grown in the substrates enriched sugarcane bagasse and coconut powder (Figure 1e). In this compartment, higher $\mathrm{K}$ content was obtained in plants grown in the substrate commercial substrate. Considering the point of maximum $\mathrm{K}$ accumulation in the shoots (at slowrelease fertilizer dose of $9.80 \mathrm{~kg} \mathrm{~m}^{-3}$ ), the substrate commercial substrate allowed increase of 4.6 times compared with the absence of slow-release fertilizer application. $\mathrm{K}$ accumulation in the root system was also higher in the substrate coconut powder (Figure 1f). 
The substrate commercial substrate also allowed increment in Ca contents in the shoots and roots of custard apple seedlings. Nonetheless, seedlings cultivated in the substrate coconut powder showed higher $\mathrm{Ca}$ accumulations in both compartments (Figure $1 \mathrm{~g}$ and $1 \mathrm{~h}$ ).

Mg content in the shoots was higher in the substrate commercial substrate $\left(13.14 \mathrm{mg}\right.$ plant $\left.^{-1}\right)$, whereas in the substrates coconut powder and fresh sugarcane bagasse, the contents were 10.95 and $2.75 \mathrm{mg} \mathrm{plant}^{-1}$, respectively, considering the maximum slow-release fertilizer dose (Figure 1i). In the root system, the substrate coconut powder was more effective in promoting higher $\mathrm{Mg}$ accumulation, with maximum efficiency at the estimated Slow-release fertilizer dose of $9.02 \mathrm{~kg} \mathrm{~m}^{-3}$ (Figure 1j).

Fe shoot contents of custard apple seedlings, as a function of slow-release fertilizer doses, fitted to a quadratic model for the substrates: commercial substrate and fresh sugarcane bagasse (Figure 2a). For coconut powder, Fe content increased linearly from 0.02 to $0.08 \mathrm{mg}$ plant ${ }^{-1}$ between the lowest and highest slow-release fertilizer dose.
In custard apple seedling roots, Fe contents were 0.17 , 0.27 and 0.31 mg plant $^{-1}$ at slow-release fertilizer doses of 9.0, 8.4 and $6.4 \mathrm{~kg} \mathrm{~m}^{-3}$ in substrates coconut powder, commercial substrate and enriched sugarcane bagasse, respectively (Figure 2b).

$\mathrm{Mn}$ and $\mathrm{Zn}$ shoot contents were higher in substrate coconut powder, with maximum values of 0.10 and $0.036 \mathrm{mg}$ plant ${ }^{-1}$ at the slow-release fertilizer dose of $15 \mathrm{~kg} \mathrm{~m}^{-3}$ (Figures $2 \mathrm{c}$ and $2 \mathrm{e}$ ). Similar data distribution was observed for shoot Mn content of custard apple seedlings grown in the substrates enriched sugarcane bagasse and commercial substrate.

For custard apple seedling roots, higher $\mathrm{Mn}$ and $\mathrm{Zn}$ contents were also found in substrate coconut powder, with the maximum estimated values of 0.056 and $0.058 \mathrm{mg} \mathrm{plant}^{-1}$ at the slow-release fertilizer doses of 11.0 and $13.3 \mathrm{~kg} \mathrm{~m}^{-3}$, respectively (Figures $2 \mathrm{~d}$ and $2 \mathrm{f}$ ).

Indexes of chlorophyll $\mathrm{a}, \mathrm{b}$ and total increased with the enhancement of the slow-release fertilizer doses (Figures $2 \mathrm{~g}$, $2 \mathrm{H}$ and $2 \mathrm{I})$. The maximum estimated indexes of chlorophyll a in the substrates fresh sugarcane bagasse, coconut powder
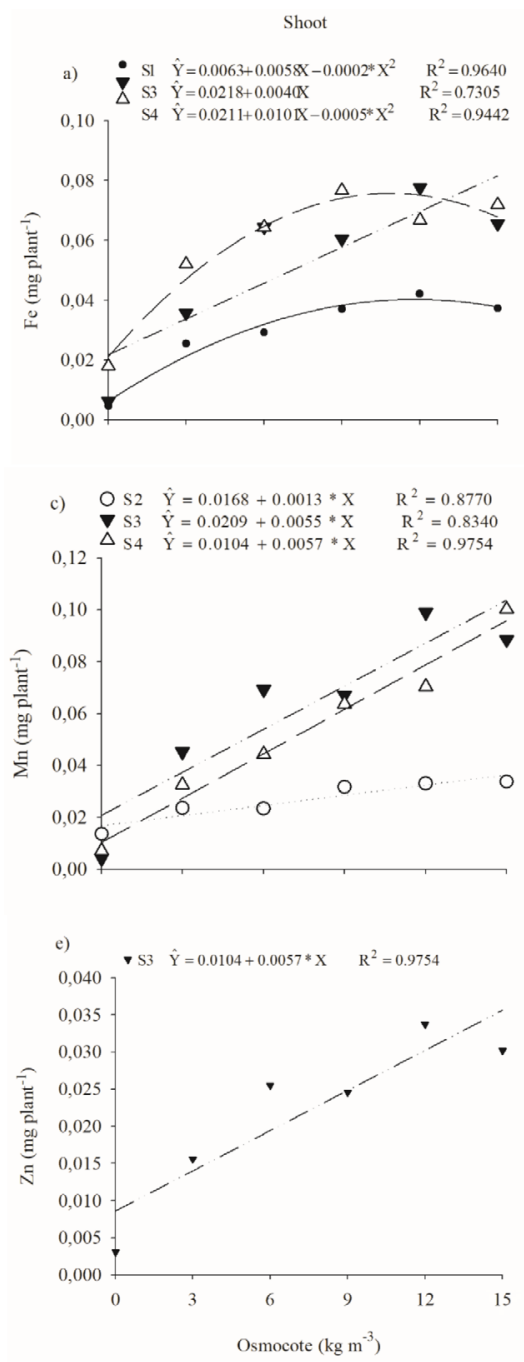

Root system
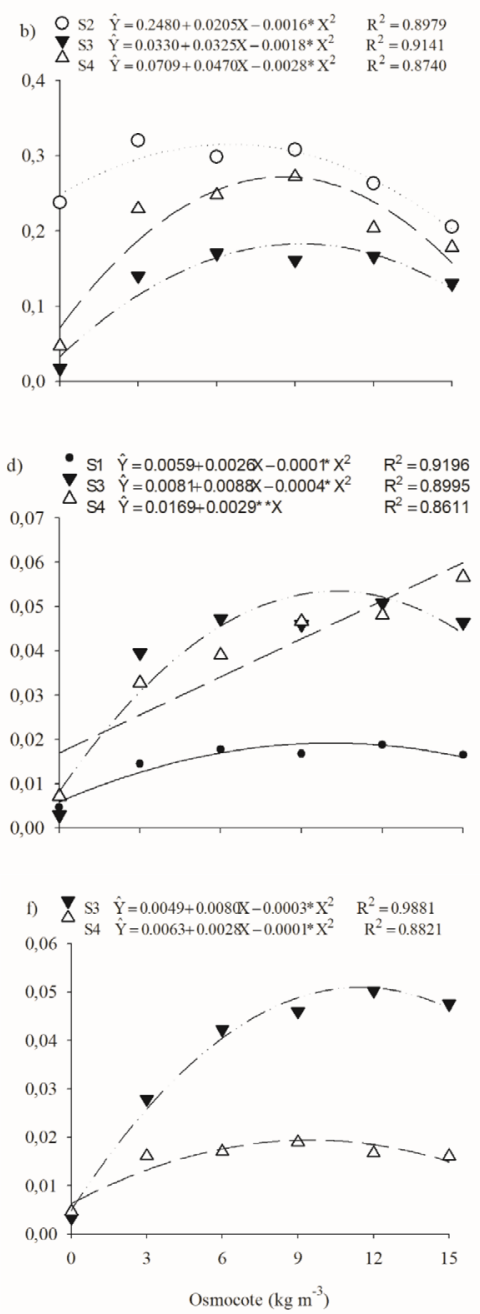

Chlorophyll
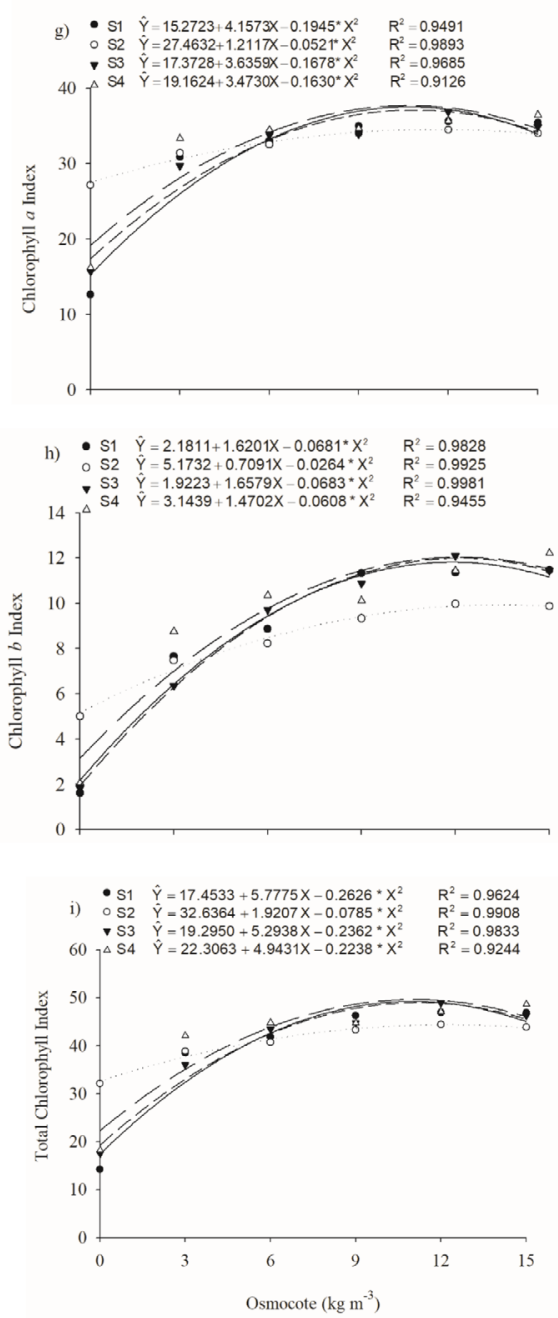

Figure 2. Contents of iron (a, b), manganese $(c, d)$ and zinc $(e, f)$ in the shoots and roots of custard apple seedlings and index of chlorophyll a (a), chlorophyll b (b) and total chlorophyll (c) as a function of different substrates and doses of slow-release fertilizer. **, *significant at 0.01 and 0.05 probability levels by t-test, respectively. S1: fresh sugarcane bagasse; S2: Enriched sugarcane bagasse; S3: Coconut powder; and S4: Commercial substrate. 
and commercial substrate were $37.91,37.95$ and 37.97 at slow-release fertilizer doses of $10.9,11.3$ and $10.8 \mathrm{~kg} \mathrm{~m}^{-3}$, respectively (Figure $2 \mathrm{~g}$ ). The substrate enriched sugarcane bagasse promoted the maximum estimated value of 34.8 at the slow-release fertilizer dose of $12 \mathrm{~kg} \mathrm{~m}^{-3}$ (Figure $2 \mathrm{~g}$ ). Similar data distribution was found for chlorophyll b and total chlorophyll indexes, with increments of 2.2 times in total chlorophyll (commercial substrate) compared with the slowrelease fertilizer dose of $0.0 \mathrm{~kg} \mathrm{~m}^{-3}$.

Absorption efficiency index (AEI) in custard apple seedlings tend to increase with the increment in slow-release fertilizer doses and were influenced by the substrate (Figure 3 ). This result is clear in the $\mathrm{AEI}$ for $\mathrm{N}$ (Figure $3 \mathrm{a}$ ) and $\mathrm{P}$ (Figure $3 \mathrm{~b}$ ).

In the absence of slow-release fertilizer, AEI values for $\mathrm{N}$ were $0.0294,0.0427,0.0078$ and 0.0090 in seedlings grown in fresh sugarcane bagasse, enriched sugarcane bagasse, coconut powder and commercial substrate, respectively. For
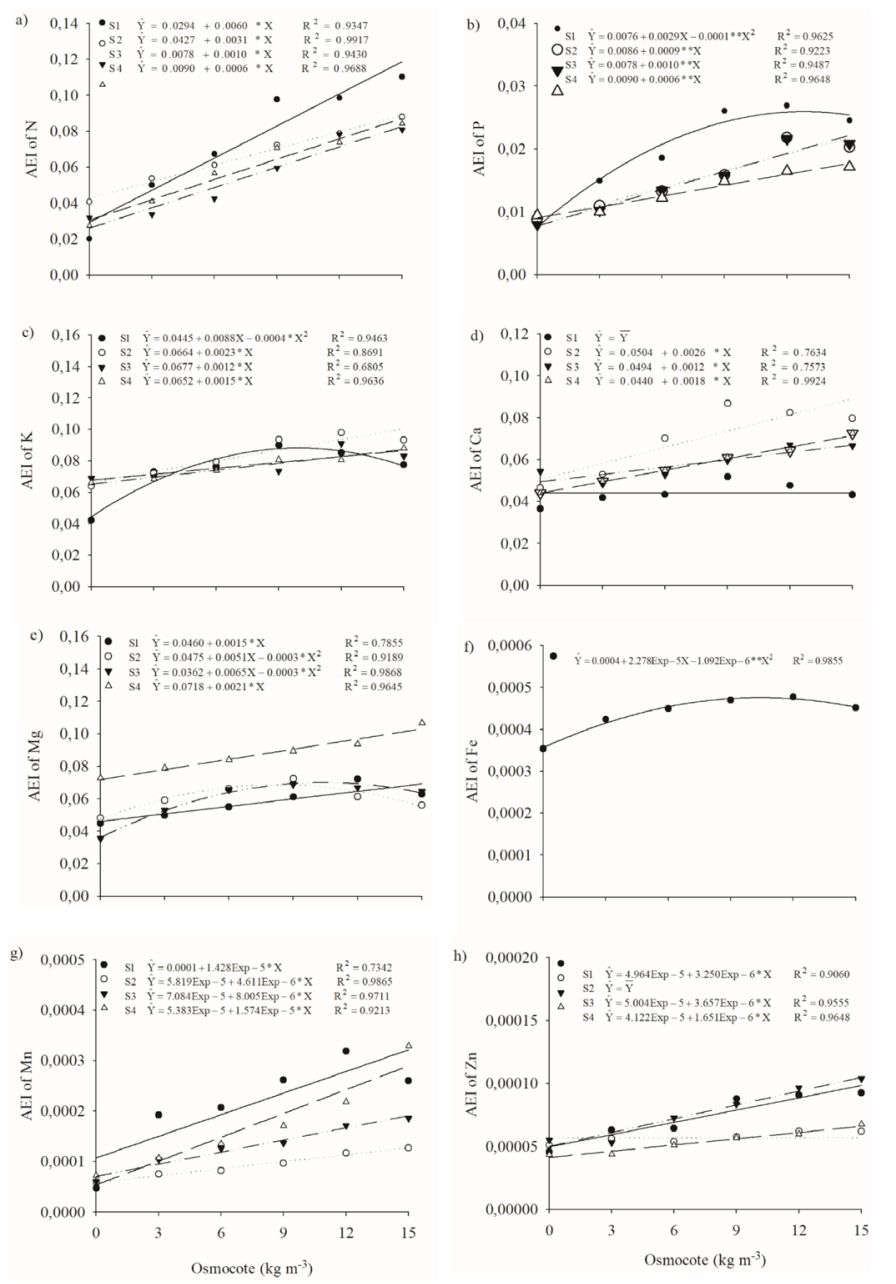

Figure 3. Absorption efficiency index for nitrogen (a), phosphorus (b), potassium (c), calcium (d), magnesium (e), iron ( $f$ ), manganese $(g)$ and zinc $(h)$ of custard apple seedlings as a function of different substrates and doses of slow-release fertilizer. **, *significant at 0.01 and 0.05 probability levels by t-test, respectively S1: fresh sugarcane bagasse; S2: Enriched sugarcane bagasse; S3: Coconut powder; and S4: Commercial substrate. the highest slow-release fertilizer dose $\left(15 \mathrm{~kg} \mathrm{~m}^{-3}\right)$, AEI values for the same substrates were $0.1194,0.0892,0.0228$ and 0.0180 , respectively, which are equivalent to increments of approximately 4.1, 2.1, 2.9 and 2 times in the AEI for $\mathrm{N}$.

For $P$, the highest AEI (0.0482) was also found for fresh sugarcane bagasse, but at slow-release fertilizer dose of 14.5 $\mathrm{kg} \mathrm{m}^{-3}$. The highest AEI values for $\mathrm{K}(0.1009), \mathrm{Ca}(0.0894)$ and $\mathrm{Mg}(0.1033)$ were observed in the substrates enriched sugarcane bagasse, enriched sugarcane bagasse and commercial substrate, respectively (Figure $3 c$, $3 d$ and $3 e$ ).

No difference was recorded in AEI values for Fe between substrates (Figure 3f), but highest AEI (0.00052) occurred at the estimated slow-release fertilizer dose of $10.43 \mathrm{~kg} \mathrm{~m}^{-3}$. $\mathrm{AEI}$ values for $\mathrm{Mn}$ and $\mathrm{Zn}$ increased as a function of slowrelease fertilizer doses (Figure $3 g$ and $3 h$ ), except the AEI for $\mathrm{Zn}$ in custard apple seedlings grown in the substrate enriched sugarcane bagasse (Figure $3 \mathrm{~h}$ ).

\section{Discussion}

The hypothesis that gradual increase in $\mathrm{N}$ availability to custard apple seedlings allows higher accumulation of nutrients in shoots and roots has been confirmed in the present study. It was also possible to observe that the seedlings' response is different according to the substrate.

The greatest difference in $\mathrm{N}$ shoot content of custard apple seedlings between the absence of slow-release fertilizer and its maximum dose was obtained in the substrate coconut powder. Such response may be associated with the physical characteristics of coconut powder (high moisture and porosity, Table 1). Moreover, higher $P$ accumulation in coconut powder, both in shoots and roots, may have allowed greater access to $\mathrm{N}$ by the seedlings, since higher $\mathrm{P}$ absorption tends to enhance root system development (Taiz et al., 2018). Such higher $N$ accumulation stimulates vegetative development, because this nutrient is a constituent of various molecules that induce the production of phytohormones, such as gibberellins and indole acetic acid, besides participating in chloroplasts and other cell components (São José et al., 2014).

In cherimoya and custard apple under $\mathrm{N}$ deficiency, older leaves become pale green to yellowish and dull, and there is a reduction in plant growth and leaf size, and plant growth may even be paralyzed (São José et al., 2014).

In this context, the substrates fresh sugarcane bagasse, enriched sugarcane bagasse and commercial substrate may have limited the absorption of $\mathrm{N}$ and $\mathrm{P}$, causing a reduction in their contents from a certain dose of slow-release fertilizer due to the possible decrease in seedling growth (Figure 1a to $1 d$ ). The substrate characterization (Table 1) clearly demonstrates that fresh sugarcane bagasse, enriched sugarcane bagasse and commercial substrate had lower moisture, which may lead to lower absorption of some nutrients, especially $P$, which is characteristically translocated by diffusive flow, a process highly dependent on the volumetric water content in the substrate (Taiz et al., 2018). 
On the other hand, despite showing a quadratic data distribution for all substrates, $\mathrm{K}$ root accumulation of custard apple seedlings was high, evidencing high absorption rate by plants, being the second most absorbed nutrient, lower than $\mathrm{N}$ only (Silva et al., 2017). $\mathrm{K}$ is the nutrient exported in greatest amount by soursop and the second most exported by custard apple (São José et al., 2014). These authors also claim that, in Annonaceae species, $\mathrm{K}$ is fundamental from the initial seedling growth stage to the fruit production stage. Hence, considering the $\mathrm{K}$ root system content, coconut powder provides better conditions for seedlings to perform the physiological processes influenced by $\mathrm{K}$, such as meristematic growth (Zhang et al., 2020) and stomatal activity (Nguyen et al., 2017).

In the seedling development stage, due to higher $\mathrm{Ca}$ accumulations in both plant compartments, the substrate coconut powder can be more effective than the others, since $\mathrm{Ca}$ is important for plant resistance to diseases (cell wall protection) and performs essential biochemical functions, besides supporting many metabolic processes (Thor, 2019).

Custard apple seedlings grown in enriched sugarcane bagasse and commercial substrate substrate showed higher Fe contents, because these substrates have higher contents of this nutrient (Table 1). Fe is related to various metabolic activities, participating in the formation of some enzymes (catalase, peroxidase, cytochrome oxidase and xanthine oxidase), and it is crucial for plant respiration, photosynthesis, $\mathrm{N}_{2}$ fixation and electron transfer between $\mathrm{Fe}^{2+}$ and $\mathrm{Fe}^{3+}$ (Taiz et al., 2018).

Rezende et al. (2010) evaluated the nutritional status of citrus seedlings along their development in protected environment, under irrigation, and observed that greater amounts of micronutrients ( $\mathrm{Fe}, \mathrm{Mn}$ and $\mathrm{Zn}$ ) were present in roots, which demonstrates that roots became storage organs for the excess of nutrient absorbed by the plant. Tecchio et al. (2006) obtained similar results evaluating growth and nutrient accumulation in Swingle citrumelo rootstock grown in substrate and found higher $\mathrm{Mn}$ and Fe accumulation roots.

Adequate micronutrients supply, especially $\mathrm{Fe}$, is essential to maintain the green color in custard apple leaves. The $\mathrm{N}$ addition through slow-release fertilizer allowed higher chlorophyll index in custard apple seedlings. Besides the contribution of $\mathrm{N}$ to chlorophyll synthesis, Fe plays an important role in the maintenance of high chlorophyll indexes, since it effectively participates in the light reaction stages of the photosynthetic process. Liu et al. (2017) observed, in Arabidopsis thaliana, increase in the expression of ethylene response factor ERF72 in leaves and roots of plants under Fe deficiency. In addition, these authors found that ERF72 directly binds to the promoter regions of the $\mathrm{CLH} 1$ chlorophyll degradation gene to regulate its expression, decreasing chlorophyll content in the leaves and causing chlorosis under Fe deficiency conditions.

Not less important, Mg plays essential role in chlorophyll synthesis, forming Mg-porphyrins (Malavolta et al., 1997). The same authors argue that Fe is involved in chlorophyll synthesis as well. They also claim that about $80 \%$ of Fe in green leaves is located in the chloroplasts, and when there is deficiency of this micronutrient, chlorophyll content and number of chloroplasts are reduced. Hence, it is possible to infer that slow-release fertilizer addition to the substrates - besides their composition - provides sufficient amounts of $\mathrm{Mg}$ and $\mathrm{Fe}$ for the synthesis of chlorophyll $a, b$ and total.

$A E I$ values for the analyzed nutrients were affected by the substrates and slow-release fertilizer doses, demonstrating that $A E I$ tends to increase as the availability of nutrients increases.

The studied slow-release fertilizer has different proportions of macro- and micronutrients and, because of that, the increment in fertilizer doses and consequent proportional increment in each nutrient may have positively influenced the AEI for each nutrient studied. Moreover, there may have been positive interaction between nutrients, allowing higher AEI with the increasing doses of the slow-release fertilizer. Xavier \& Natale (2017) observed positive interaction between B and $\mathrm{N}$ in starfruit rootstocks, which showed higher $\mathrm{N}$ absorption efficiency with the increment in B doses.

AEI depends on the demand of each nutrient and on the plant species studied, besides the physical characteristics of the soil or substrates (Huygens \& Saveyn, 2018). This index was devised by Swiader et al. (1994) and indicates the nutrient uptake capacity by plants in the cultivation medium based on root system dry matter.

In custard apple seedlings, the sequence of $A E I$ for nutrients was $\mathrm{N}>\mathrm{Mg}>\mathrm{K}>\mathrm{Ca}>\mathrm{P}>\mathrm{Fe}>\mathrm{Mn}>\mathrm{Zn}$. Silva-Matos et al. (2015), evaluating yellow passion fruit seedlings in different substrates containing proportions of decomposed buriti trunk and boron, observed that $A E I$ obeyed the following decreasing order of macronutrients: $N>K>P$. This indicates that characteristics of the plant species, substrate and type of fertilizer play an important role in the preference of absorption of nutrients.

\section{Conclusions}

The organic substrates and the slow-release fertilizer doses affect the macro- and micronutrients contents and indexes of chlorophyll a, b and total in custard apple seedlings.

Higher nutrient availability enhances the respective nutrient absorption indexes (AEI) in custard apple seedlings.

Coconut powder associated with $9 \mathrm{~kg} \mathrm{~m}^{-3}$ slow-release fertilizer dose is efficient to produce custard apple seedlings.

\section{Compliance with Ethical Standards}

Author contributions: Conceptualization: AMNL, IHLC, JCFMJ; Formal analysis: SAA; Investigation: SAA, Dayanne do Nascimento Dias; Project administration: AMNL; Resources: JCFMJ; Supervision: AMNL, IHLC; Validation: SAA; Writing original draft: SAA; Writing - review \& editing: AMNL; JCC; KAS; MSR.

Conflict of interest: The authors declare that there is no conflict of interest (professional or financial) that could influence the article. 
Financing source: For the execution of the research there was no financial support from funding sources.

\section{Literature Cited}

Almeida, U.O.; Andrade Neto, R.C.; Araujo, J.M.; Costa, D.A.; Teixeira Júnior, D.L.T. Fertilizantes de liberação lenta na produção de mudas frutiferas. South American Journal of Basic Education, Technical and Technological, v.6, n.1, p.518-527, 2019. https:// periodicos.ufac.br/index.php/SAJEBTT/article/view/2188.

Barreto, M.C.S; Dias, A.L.F; Figueiredo, M.V.B; Farias, C.H.A.; Barbosa, M.R.; Santos, A.A.; Andrade, A.G. Aclimatização de mudas pré-brotadas de cana-de-açúcar em diferentes substratos. In: Amormino Júnior, M. (Ed.). Elementos da natureza e propriedades do solo. Ponta Grossa: Atena Editora, 2018. v. 2, p. 8-16.

Cavalcante, L.F.; Pereira, W.E.; Curvêlo, C.R.S.; Nascimento, J.A.M.; Cavalcante, I.H.L. Estado nutricional de pinheira sob adubação orgânica do solo. Revista Ciência Agronômica, v.43, n.3, p.579588, 2012. https://doi.org/10.1590/S1806-66902012000300022.

Huygens, D.; Saveyn, H.G.M. Agronomic efficiency of selected phosphorus fertilisers derived from secondary raw materials for European agriculture. A meta-analysis. Agronomy for Sustainable Development, v.38, e52, 2018. https://doi.org/10.1007/s13593018-0527-1.

Liu, W.; Li, Q.; Wang, Y.; Wu, T.; Yang, Y.; Zhang, X.; Han, Z.; Xu, $X$. Ethylene response factor AtERF72 negatively regulates Arabidopsis thaliana response to iron deficiency. Biochemical and Biophysical Research Communications, v.491, n.3, p.862868, 2017. https://doi.org/10.1016/j.bbrc.2017.04.014.

Malavolta, E.; Vitti, G.C.; Oliveira, S.A. Avaliação do estado nutricional das plantas: Princípios e aplicações. 2 ed. Piracicaba: Potafos, 1997. 319p.

Brasil. Ministério da Agricultura, Pecuária e Abastecimento. Secretaria de Defesa Agropecuária. Instrução Normativa SDA no 17, de 21 de maio de 2007. Aprova os métodos analíticos oficiais para análise de substratos e condicionadores de solos. Diário Oficial da União, v.144, n.99, seção 1, p.8-9, 2007. https://www. gov.br/agricultura/pt-br/assuntos/insumos-agropecuarios/ insumos-agricolas/fertilizantes/legislacao/in-17-de-21-05-2007aprova-metodo-substrato.pdf. 19 Mar. 2021.

Melo Júnior, J.C.F.; Costa, D. S.; Gervásio, E.S.; Lima, A.M.N.; Sediyama, G.C. Efeito de níveis de depleção de água no substrato e doses de fertilizante de liberação controlada na produção de mudas de maracujazeiro amarelo. Irriga, v.20, n.2, p.204-219, 2015. https://doi.org/10.15809/irriga.2015v20n2p204.

Nguyen, T.H.; Huang, S.; Meynard, D.; Chaine, C.; Michel, R.; Roelfsema, M.R.G.; Guiderdoni, E.; Sentenac, H.; Véry, A.A. A dual role for the OsK5.2 ion Channel in stomatal movements and $\mathrm{K}^{+}$loading into xylem sap. Plant Physiology, v.174, p.2409-2418, 2017. https://doi.org/10.1104/pp.17.00691
Rezende, C.F.A.; Fernandes, E.P.; Silva, M.F. Da.; Leandro, W.M. Crescimento e acúmulo de nutrientes em mudas cítricas cultivadas em ambiente protegido. Bioscience Journal, v.26, n.3, p.367-375, 2010. http://www.seer.ufu.br/index.php/ biosciencejournal/article/view/7106. 19 Mar. 2021.

Sá, T.S.; Gervásio, E.S.; Galhardo, C.X.; Silva, V.P. Caracterização físicohídrica e química de substratos à base de fibra de coco. In: Inovagri International Meeting, 3., 2015, Fortaleza. Anais... Fortaleza: Inovagri; INI, 2015. p.182-191. https://doi.org/10.12702/iii. inovagri.2015-a020.

São José, A.R.; Prado, N.B.; Bomfim, M.P.; Rebouças, T.N.H.; Mendes, H.T.A.E. Marcha de absorção de nutrientes em anonáceas. Revista Brasileira de Fruticultura, v.36, spe.1, p.176-183, 2014. http://doi.org/10.1590/S0100-29452014000500021.

Silva, E.B.; Ferreira, E.A.; Pereira, G.A.M.; Silva, D.V.; Oliveira, A.J.M. Absorção de nutrientes e crescimento de plantas de amendoim. Revista Caatinga, v.30, n.3, p.653-661, 2017. http://doi. org/10.1590/1983-21252017v30n313rc.

Silva-Matos, R.R.S.; Silva Junior, G.B.; Marques, A.S.; Monteiro, M.L.; Cavalcante, I.H.L.; Osajima, J.A. Nutrient concentrations and leaf chlorophyll of yellow passion fruit seedlings as a function of substrate composition and boron. Journal of Plant Nutrition, v.38, n.13, p.1984-1994, 2015. https://doi.org/10.1080/019041 67.2015.1061545.

Swiader, J.M.; Chyan, Y.; Freiji, F.G. Genotypic differences in nitrate uptake and utilization efficiency in pumpkin hybrids. Journal of Plant Nutrition, v.17, n.10, p.1687-1699, 1994. https://doi. org/10.1080/01904169409364840.

Taiz, L.; Zeiger, E.; Möller, I. M.; Murphy, A. Plant physiology and development. 6.ed. Oxford: Oxford University Press, 2018. 756p.

Tecchio, M.A.; Leonel, S.; Lima, C.P.; Villas Boas, R.L.; Almeida, E.L.P.; Corrêa, J.C. Crescimento e acúmulo de nutrientes no portaenxerto citrumelo "swingle" cultivado em substrato. Bioscience Journal, v.22, n.1, p.37-44, 2006. http://www.seer.ufu.br/index. php/biosciencejournal/article/view/6637/4364. 29 Mar. 2021.

Teixeira, P.C.; Donagemma, G.G.; Fontana, A.; Teixeira, W.G. Manual de métodos de análise de solos. 3.ed. Brasília: Embrapa, 2017. $573 p$.

Thor, K. Calcium - nutrient and messenger. Frontiers in Plant Science, v.10, p.440-454, 2019. https://doi.org/10.3389/fpls.2019.00440.

Xavier, C.V.; Natale, W. Influência do boro no teor, acúmulo e eficiência nutricional em porta-enxertos de caramboleira. Revista Brasileira de Ciências Agrárias, v.12, n.1, p.6-13, 2017. https:// doi.org/10.5039/agraria.v12i1a5409.

Zhang, M-L; Huang, P-P.; Ji, Y.; Wang, S.; Wang, S-S.; Li, Z.; Guo, Y.; Ding, Z.; Wu, W-H.; Wang, Y. KUP9 maintains root meristem activity by regulating $\mathrm{K}^{+}$and auxin homeostasis in response to low K. EMBO Reports, v.21, e50164, 2020. https://doi.org/10.15252/ embr.202050164. 